\title{
Angioplasty of forearm arteries as a finger salvage procedure for patient with end-stage renal failure
}

This article was published in the following Dove Press journal: International Journal of Nephrology and Renovascular Disease 18 April 2016

Number of times this article has been viewed

\author{
Yuk Law \\ Yiu Che Chan \\ Stephen Wing-Keung Cheng \\ Division of Vascular and Endovascular \\ Surgery, Department of Surgery, \\ University of Hong Kong Medical \\ Centre, Queen Mary Hospital, Hong \\ Kong
}

\begin{abstract}
Due to the relatively low metabolic demand and extensive collaterals of the upper limb, peripheral arterial disease seldom leads to tissue loss, except in patients with end-stage renal failure (ESRF), rheumatologic diseases, Raynaud's disease, frostbites, or distal emboli. We report a case of a 51-year-old lady with ESRF who presented to our tertiary referral vascular center with infected gangrene of her right ring finger. Duplex ultrasound showed that her forearm arteries were severely diseased. Digital subtraction angiogram showed severe multilevel stenoses/ occlusions in her forearm radial and ulnar arteries. These lesions were successfully angioplastized with $2 \mathrm{~mm} \times 25 \mathrm{~mm}$ angioplasty balloon. Completion angiogram showed good radiological results with some post-dilatation spasm which improved with intra-arterial glyceryl trinitrate. The sepsis improved after revascularization, and the distal phalanx was allowed to self-demarcate with dressings and autoamputate with good clinical results. Our case illustrated that even in delayed setting, patients could still benefit from specialist vascular care with a combination of expert care and angioplasty of forearm arteries, with successful salvage of her finger.
\end{abstract}

Keywords: end-stage renal disease, finger septic gangrene, peripheral arterial disease, angioplasty, salvage

\section{Introduction}

Peripheral vascular disease of upper extremity seldom leads to tissue loss because of the relatively low metabolic demand and extensive collaterals of upper limb. Patients with end-stage renal failure (ESRF) are more prone to finger gangrene, especially those with multilevel stenosis or calcification involving the forearm vessels, as shown in clinical and autopsy studies. ${ }^{1}$ This is also particularly important in patients with elbow-based arteriovenous fistula for hemodialysis, as there is a danger of arterial steal. Other differential diagnoses included rheumatological diseases, Raynaud's disease, frostbites, or distal emboli. Many patients with finger gangrene presented to orthopedic surgeons for primary amputation, but there are more reports ${ }^{2-9}$ now of revascularization of forearm arteries to be a useful adjunct for finger salvage.

We report a case of successful angioplasty of forearm arteries in a patient with Division of Vascular and Endovascular Surgery, Department of Surgery, University of Hong Kong Medical Centre, South Wing, 14th Floor K Block, Queen Mary Hospital, Pokfulam Road, Hong Kong

Tel +852 22554962

Fax +85222554961

Email ycchan88@hkucc.hku.hk
ESRF, and thereby saving her finger, with good clinical and functional outcome.

\section{Case}

A 51-year-old right-handed lady with ESRF presented with a 2 months' history of progressively worsening infected gangrene involving her right ring finger which developed after a nail clipping injury. Past medical history was significant for 20 years of ESRF 
due to unknown etiology, currently on hemodialysis via a right neck PermCath catheter, hypertension, and percutaneous coronary angioplasty via a right femoral access.

On presentation, her right hand was pale and there was infected gangrene of her right ring finger, which was edematous and inflammed and spreading to the proximal pharynx. Her right radial and ulnar pulses were absent at the wrist, but her brachial pulse was palpable. She was started on Unasyn (ampicillin and sulbactam) empirically. Duplex ultrasound (Philips iU22; Philips Healthcare Solutions, Bothell, WA, USA) showed severe multilevel stenosis of the forearm radial artery and occlusion of the forearm ulnar artery. The brachial, axillary, and subclavian arteries were calcified but patent. The ultrasound criteria of moderate stenosis (50\%)

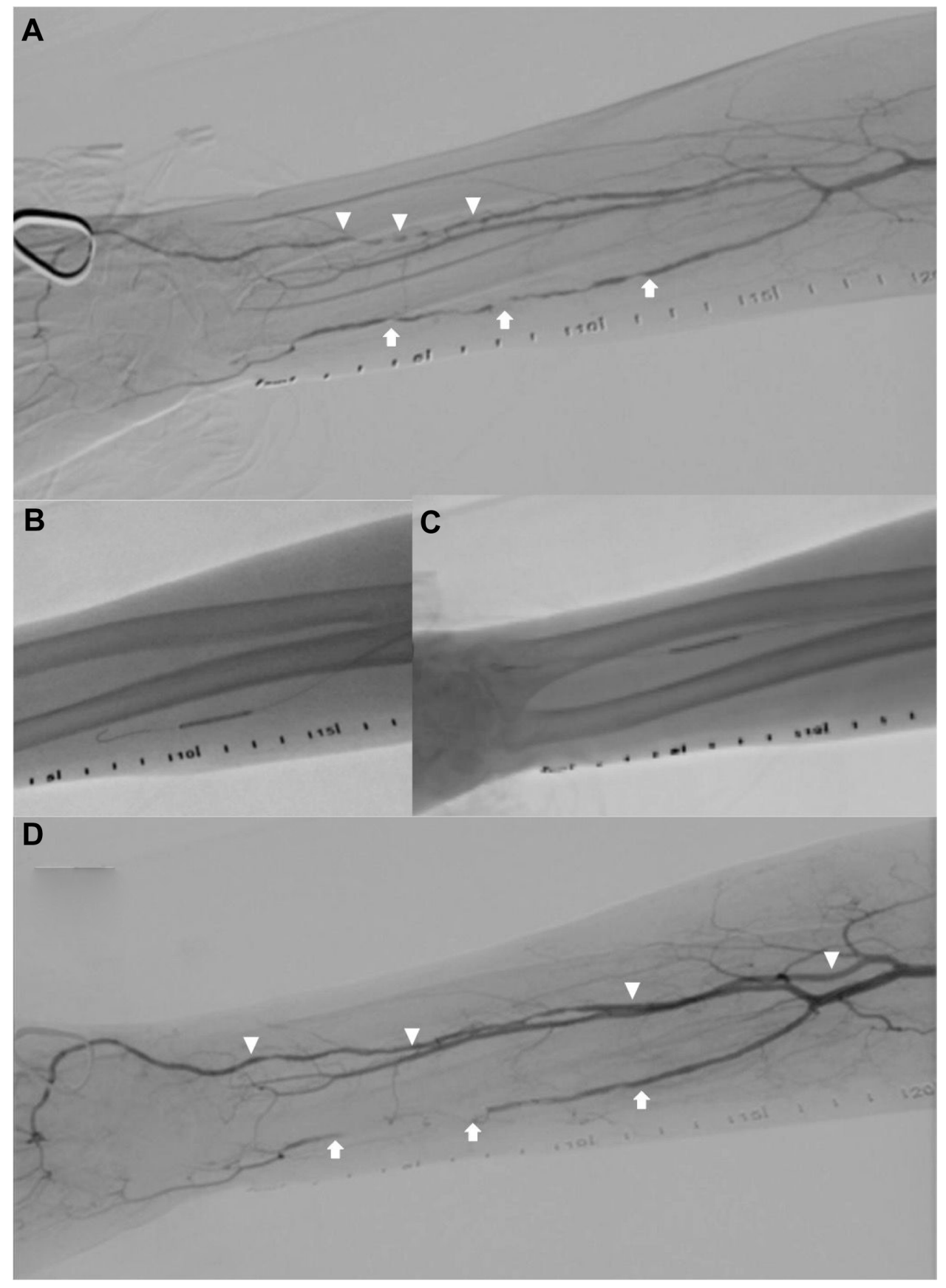

Figure I Angioplasty of forearm arteries.

Notes: (A) On-table angiogram showed multiple segment stenoses over right radial artery (triangles) and ulnar artery (arrows). (B) Angioplasty of ulnar artery. (C) Angioplasty of radial artery. (D) Successful revascularization of radial artery (triangles). Spasm of ulnar artery (arrows) after angioplasty was improved with intra-arterial gylceryl trinitrate. 
was at-stenosis and pre-stenosis velocity ratio of more than or equal to 2.0 , or a peak systolic velocity of more than or equal to $200 \mathrm{~cm} / \mathrm{s}$. Criteria of severe stenosis (75\%) was velocity ratio of more than or equal to 4.0 , or peak systolic velocity of more than or equal to $400 \mathrm{~cm} / \mathrm{s}$.

In view of the duplex findings, urgent revascularization of forearm arteries was arranged. Brachial access was established at the antecubital fossa, with antegrade insertion of a 4-French sheath (Cordis Corporation, Fremont, CA, USA). On-table angiogram showed multilevel mid to distal ulnar artery occlusion and severe mid to distal radial artery stenoses. All the lesions were passed intraluminally with 0.018/0.014" Terumo guidewire (Terumo Medical Corporration, Somerset, NJ, USA) and angioplastized with $2 \mathrm{~mm} \times$ $25 \mathrm{~mm}$ Medtronic Sprinter Legend balloon (Medtronic Inc, Fridley, MN, USA). Completion angiogram showed satisfactory radiological result with some ulnar artery spasm which improved with $50 \mu \mathrm{g}$ of intra-arterial glyceryl trinitrate (UCB Pharma Limited, Berkshire, UK) (Figure 1).

The wound swab grew Citrobacter, and her finger infection was controlled by giving Unasyn (ampicillin and sulbactam) for 2 weeks. She was discharged on postoperative day 5. Clopidogrel and aspirin were given for 3 months and then was advised to continue clopidogrel lifelong. The distal phalanx autoamputated with no wound after 3 months (Figure 2). The radial pulse was still easily palpable at 1 year follow-up. Apart from clinical and duplex ultrasound outcomes, digital pressure was also a good indicator of revascularization, although this was not measured in our patient. The patient gave informed written consent to publication of this report. Angioplasty of forearm arteries is a standard treatment in our territory and this paper does not require the Institutional Review Board of the University of Hong Kong/Hospital Authority Hong Kong West Cluster to review.

\section{Discussion}

Digital gangrene due to chronic atherosclerotic disease is rare due to low metabolic demand and extensive collateral circulation, ${ }^{10}$ except in patients with ESRF, rheumatological diseases, Raynaud's disease, frostbites, or distal emboli. Patients with renal failure are more prone to develop occlusive disease of the upper limb. Acceleration of atherosclerosis, upregulation of markers of inflammation and oxidative stress, and more severe calcification of plaques and the arterial media among ESRF patients were possible mechanisms. ${ }^{1}$ Steal from ipsilateral concomitant arteriovenous fistulae also contributed to some cases of hand ischemia. ${ }^{11}$

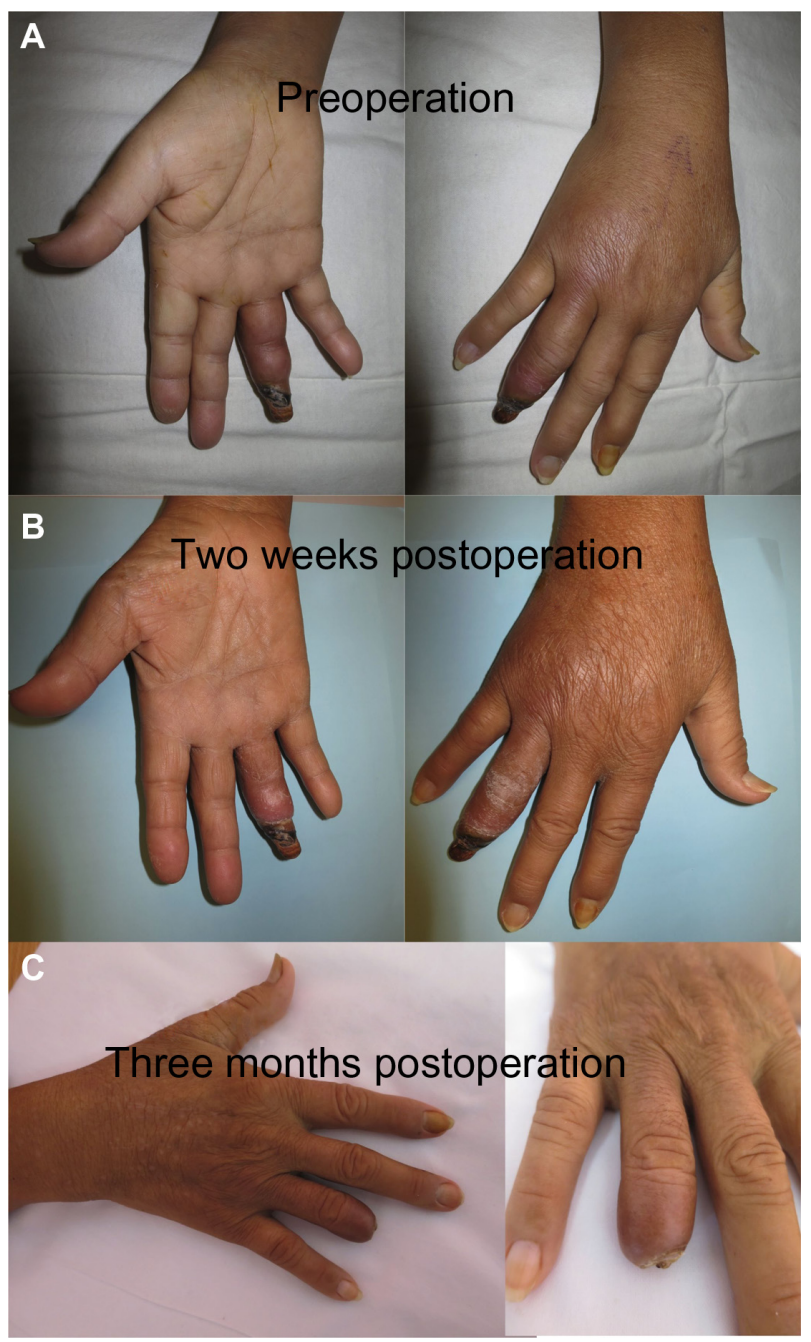

Figure 2 Serial clinical photos of patient's ring finger over time.

Notes: (A) Distal phalanx was gangrenous with cellulitis of middle and proximal phalanx at presentation before revascularization. (B) Two weeks postoperation and (C) 3 months postoperation when the ring finger has autoamputated with no pain or open wound.

There is a relative paucity of literature on endovascular treatment of upper extremity arterial disease compared to lower limb, with medical therapy involving antiplatelet agents and lifestyle and risk factor modifications being the mainstay of treatment. ${ }^{12}$ Many patients with septic digital gangrene had primary amputation by the orthopedic services, without preoperative careful vascular assessment or even consideration for revascularization. Forearm bypass graft is now seldom necessary. Chang et al ${ }^{13}$ reported 18 forearm bypass procedures for digital ulceration or gangrene with patency rate of $88.9 \%$ at mean follow-up of 18 months. Systematic review of 16 studies reporting outcomes of distal upper extremity bypass surgery showed an overall patency rate of $87 \%$ at an average follow-up of 34 months among 152 bypass grafts performed. ${ }^{14}$ 
Table I Contemporary case report or cohort on endovascular revascularization of forearm arteries

\begin{tabular}{|c|c|c|c|c|c|}
\hline Author & $\begin{array}{l}\text { Number } \\
\text { of cases }\end{array}$ & $\begin{array}{l}\text { Presentation/ } \\
\text { comorbidities }\end{array}$ & $\begin{array}{l}\text { Involved forearm } \\
\text { arteries }\end{array}$ & Revascularization procedure & Outcome \\
\hline Dineen et $\mathrm{a}^{2}$ & 1 & $\begin{array}{l}\text { Gangrenous third } \\
\text { to fifth fingers in an } \\
\text { end-stage renal failure } \\
\text { (ESRF) patient. }\end{array}$ & $\begin{array}{l}\text { Proximal radial } \\
\text { artery }\end{array}$ & $\begin{array}{l}\text { Percutaneous brachial access; } \\
\text { Angioplasty with } 2.5 \times 120 \mathrm{~mm}^{2} \\
\text { Amphirion balloon (ev3, Plymouth, } \\
\text { MN, USA); } \\
\text { Stenting with three Expert stents } \\
3 \times 30 \mathrm{~mm}^{2}, 3 \times 40 \mathrm{~mm}^{2}, 4 \times 40 \mathrm{~mm}^{2} \\
\text { (Abbott Vascular, Redwood City, } \\
\text { CA, USA). }\end{array}$ & $\begin{array}{l}\text { All fingers healed } \\
\text { except minor scabbing } \\
\text { of third finger. } \\
\text { Stent was patent } \\
\text { at } 6 \text { months on } \\
\text { angiography. }\end{array}$ \\
\hline Namdari et al ${ }^{3}$ & I & $\begin{array}{l}\text { Poor healing of index } \\
\text { finger amputation } \\
\text { wound and gangrenous } \\
\text { middle finger. }\end{array}$ & Distal radial artery & $\begin{array}{l}\text { Open brachial access; } \\
\text { Angioplasty with } 2 \mathrm{~mm} \text { balloon. }\end{array}$ & $\begin{array}{l}\text { Wound healed at } \\
\text { I month. Radial } \\
\text { pulse was palpable at } \\
21 \text { months. }\end{array}$ \\
\hline Gandini et $\mathrm{al}^{4}$ & 1 & $\begin{array}{l}\text { Digital ulceration of } \\
\text { ring finger in an ESRF } \\
\text { patient. }\end{array}$ & Ulnar artery & $\begin{array}{l}\text { Brachial access; } \\
\text { Angioplasty of distal part of ulnar } \\
\text { artery through the superficial Palmar } \\
\text { arch with } 2 \times 80 \mathrm{~mm}^{2} \text { Amphirion } \\
\text { Deep balloon (Invatec, Brescia, Italy). }\end{array}$ & $\begin{array}{l}\text { Complete wound } \\
\text { healing observed at } \\
6 \text { months. }\end{array}$ \\
\hline Kawarada et $\mathrm{al}^{5}$ & 5 & $\begin{array}{l}\text { Five critical hand } \\
\text { ischemia in ESRF } \\
\text { patients. }\end{array}$ & $\begin{array}{l}\text { Target vessels were } \\
\text { ulnar artery in four, } \\
\text { radial artery in one } \\
\text { and palmar arch } \\
\text { in two. }\end{array}$ & $\begin{array}{l}\text { Percutaneous brachial access. } \\
\text { Monorail balloon (Ikazuchi; Kaneka } \\
\text { Medix Corp., Osaka, Japan) or over- } \\
\text { the-wire balloon (Genity; Kaneka } \\
\text { Medix Corp., Osaka, Japan or Fox- } \\
\text { SV; Abbott Vascular, Santa Clara, } \\
\text { CA, USA) }\end{array}$ & $\begin{array}{l}\text { Clinical success in all } \\
\text { with mean follow-up } \\
\text { period of II months. }\end{array}$ \\
\hline Itaya et a $\left.\right|^{6}$ & 1 & $\begin{array}{l}\text { Ring finger ulcer in an } \\
\text { ESRF patient. }\end{array}$ & $\begin{array}{l}\text { Brachial and ulnar } \\
\text { artery }\end{array}$ & $\begin{array}{l}\text { Femoral access with monorail balloon } \\
\text { (lkazuchi; Kaneka Medix Corp.) } \\
\text { angioplasty of brachial stenosis. } \\
\text { Then, brachial access with monorail } \\
\text { balloon (Ikazuchi; Kaneka Medix } \\
\text { Corp.) angioplasty of ulnar stenosis. }\end{array}$ & $\begin{array}{l}\text { Wound healed at } \\
\text { I month. Patient } \\
\text { was symptom free at } \\
6 \text { months. }\end{array}$ \\
\hline Tasal et $\mathrm{al}^{7}$ & 1 & $\begin{array}{l}\text { Ringer finger } \\
\text { ulceration in an ESRF } \\
\text { patient. }\end{array}$ & Distal radial artery & $\begin{array}{l}\text { Femoral access. } \\
\text { Angioplasty with } 2 \times 80 \mathrm{~mm}^{2} \text { and } \\
2.5 \times 100 \mathrm{~mm}^{2} \text { peripheral balloon } \\
\text { (Fox SV; Abbott Vascular) }\end{array}$ & $\begin{array}{l}\text { Finger healed at } \\
2 \text { months. }\end{array}$ \\
\hline Jaradat et $\mathrm{al}^{8}$ & 4 & $\begin{array}{l}\text { Latrogenic radial } \\
\text { artery occlusion } \\
\text { after transradial } \\
\text { catheterization. }\end{array}$ & Radial artery & $\begin{array}{l}\text { Brachial access. } \\
\text { Balloon angioplasty and abciximab } \\
\text { (Reopro; Lilly, Indianapolis, IN, USA) } \\
\text { (025 mg/kg) infused over } 90 \text { seconds } \\
\text { via a ClearWay infusion catheter. }\end{array}$ & $\begin{array}{l}\text { Patients were } \\
\text { symptom free at a } \\
\text { mean follow-up of } \\
\text { I } 80 \text { days. Three had } \\
\text { duplex-confirmed } \\
\text { patency at a mean } \\
\text { follow-up of } 229 \text { days. }\end{array}$ \\
\hline Arabi et $\mathrm{al}^{9}$ & 1 & $\begin{array}{l}\text { Ring finger gangrene in } \\
\text { an ESRF patient. }\end{array}$ & Radial artery & $\begin{array}{l}\text { Retrograde distal radial access. } \\
\text { Angioplasty with } 2 \times 80 \mathrm{~mm}^{2} \text { and } \\
3.5 \times 80 \mathrm{~mm}^{2} \text { Amphirion Deep } \\
\text { balloon (Medtronic Inc, Mineapolis, } \\
\text { MN, USA) }\end{array}$ & $\begin{array}{l}\text { Partial healing at } \\
\text { I month. Amputation } \\
\text { of distal and middle } \\
\text { phalanges at } 2 \text { months } \\
\text { with angiographic } \\
\text { evidence of restenosis. }\end{array}$ \\
\hline
\end{tabular}

Angioplasty is an alternative option given its minimal invasive nature, but there are only a handful of cases described in contemporary literature. We performed literature search using PubMed, Ovid Medline, and EMBASE databases. Search keywords comprised angioplasty, percutaneous angioplasty, revascularization AND finger gangrene, ischemia, tissue loss. The results were reviewed individually. All studies using angioplasty as a treatment for finger gangrene due to various etiologies are included and tabulated in Table 1 . Safety and repeatability of this method were clearly demonstrated. Report on long-term efficacy of more than 1 year, however, was lacking. The aim of the treatment in our patient was infection control and the gangrenous fingertip was then allowed to autoamputate. Patency of her radial artery was still observed at 1 year follow-up. 


\section{Conclusion}

With improvements in endovascular technology and wide availability of low-profile small balloons, angioplasty of the forearm arteries should be considered for finger salvage in patients with ESRF. This report emphasized the importance of specialist vascular care with a combination of expert care and angioplasty of forearm arteries, even in delayed setting, with successful salvage of the patient's finger.

\section{Acknowledgment}

This paper was presented as: Law Y, Chan YC, Cheng SW. Successful angioplasty of Forearm arteries in a Patient with End-stage renal failure and Finger gangrene in the 16th Congress of Asian Society of Vascular Surgery, December 2015, Bangkok, Thailand.

\section{Disclosure}

The authors report no conflicts of interest in this work.

\section{References}

1. Campean V, Neureiter D, Varga I, et al. Atherosclerosis and vascular calcification in chronic renal failure. Kidney Blood Press Res. 2005; 28(5-6):280-289.

2. Dineen S, Smith S, Arko FR. Successful percutaneous angioplasty and stenting of the radial artery in a patient with chronic upper extremity ischemia and digital gangrene. J Endovasc Ther. 2007;14(3):426-428.

3. Namdari S, Park MJ, Weiss AP, Carney WI. Chronic hand ischemia treated with radial artery balloon angioplasty: case report. J Hand Surg Am. 2008;33(4):551-554.
4. Gandini R, Angelopoulos G, Da Ros V, Simonetti G. Percutaneous transluminal angioplasty for treatment of critical hand ischemia with a novel endovascular approach: "the radial to ulnar artery loop technique". J Vasc Surg. 2010;51(3):760-762.

5. Kawarada O, Yokoi Y, Higashimori A. Angioplasty of ulnar or radial arteries to treat critical hand ischemia: use of 3- and 4-French systems. Catheter Cardiovasc Interv. 2010;76(3):345-350.

6. Itaya H, Nakamura M. Novel strategy for percutaneous transluminal angioplasty for complex critical hand. Cardiovasc Interv Ther. 2012; 27(1):52-56.

7. Tasal A, Bacaksiz A, Erdogan E, Goktekin O. Successful angioplasty for radial artery chronic total occlusion in a patient with digital gangrene. Postepy Kardiol Interwencyjnej. 2013;9(3):304-306.

8. Jaradat Z, Basir B, Revtyak G. Treatment of radial artery occlusions using balloon angioplasty and localized intra-arterial abciximab. J Iterv Cardiol. 2014;27(2):217-222.

9. Arabi M, Ahmed I, Qattan N. Transluminal recanalization of chronic total occlusion of radial artery using rendezvous technique: a case report and literature review. J Clin Imaging Sci. 2014;4:36.

10. Gross WS, Flanigan P, Kraft RO, Stanley JC. Chronic upper extremity arterial insufficiency. Etiology, manifestations, and operative management. Arch Surg. 1978;113(4):419-423.

11. Valji K, Hye RJ, Roberts AC, Oglevie SB, Ziegler T, Bookstein JJ. Hand ischemia in patients with hemodialysis access grafts: angiographic diagnosis and treatment. Radiology. 1995;196(3):697-701.

12. Sabiston DC, Townsend CM. Sabiston Textbook of Surgery: The Biological Basis of Modern Surgical Practice. 19th ed. Philadelphia, PA: Elsevier Saunders; 2012.

13. Chang BB, Roddy SP, Darling RC, 3rd, et al. Upper extremity bypass grafting for limb salvage in end-stage renal failure. J Vasc Surg. 2003;38(6):1313-1315.

14. Masden DL, Seruya M, Higgins JP. A systematic review of the outcomes of distal upper extremity bypass surgery with arterial and venous conduits. J Hand Surg Am. 2012;37(11):2362-2367.

\section{Publish your work in this journal}

The International Journal of Nephrology and Renovascular Disease is an international, peer-reviewed open-access journal focusing on the pathophysiology of the kidney and vascular supply. Epidemiology, screening, diagnosis, and treatment interventions are covered as well as basic science, biochemical and immunological studies. The journal welcomes original research, clinical studies, reviews \& evaluations, expert opinion and commentary, case reports and extended reports. The manuscript management system is completely online and includes a very quick and fair peerreview system, which is all easy to use. Visit http://www.dovepress.com/ testimonials.php to read real quotes from published authors. 